\title{
Thrombosis in systemic lupus erythematosus: a French collaborative study
}

Marcela A Montes de Oca, Marie Claude Babron, Olivier Blétry, Michel Broyer, Victor Courtecuisse, Jean Loup Fontaine, Chantal Loirat, Jean-Philippe Méry, Philippe Reinert, Bertrand Wechsler, Micheline Levy

\begin{abstract}
A retrospective study was undertaken of 120 children with systemic lupus erythematosus (SLE) seen in Paris and its immediate suburbs who fulfilled at least four of the American College of Rheumatology diagnostic criteria for SLE, and in whom the disease was diagnosed before the age of 16 and between January 1975 and December 1987. Eleven of these children (eight girls and three boys) all more than 10 years of age (mean follow up 8.1 years; range 3-13) had thrombotic episodes (9\%). Thrombosis was one of the presenting signs in seven patients; in five it was associated with typical symptoms of SLE, and in the other two the thrombotic episode was isolated and diagnosis of SLE was delayed one and three years. Of a total of 16 thrombotic episodes (six of which were recurrent), 14 involved the leg veins, and in four there was associated pulmonary embolism. There were two episodes that affected cerebral arteries. The American College of Rheumatology diagnostic criteria for SLE as well as the incidence of lupus anticoagulant, positive direct Coombs test, and vasculitis in this group of patients was compared with the incidence in patients with SLE but no thrombosis. Only lupus anticoagulant was significantly associated with thrombotic episodes: eight of 11 (73\%) of patients with SLE and thrombotic (arterial or venous) episodes had lupus anticoagulant compared with only 10 of 74 patients (14\%) with no history of thrombotic events in the same age group.
\end{abstract}

Arterial and venous thrombosis in the absence of certain risk factors (infection, operations, and vascular abnormalities) are exceptional in children. Case reports have been published about thrombotic episodes in children with systemic lupus erythematosus (SLE). ${ }^{1-7}$ Because large series of children with SLE hardly mention thrombotic complications it is not possible to evaluate their prevalence or associated clinical and laboratory features in this age group. Venous and arterial thromboses are important in adult SLE, but it is difficult to evaluate their incidence because series are not always comparable. In a prospective study, Alarcon Segovia $e t$ $a l$ followed up 500 patients with SLE and found that 43 had thrombophlebitis (recurrent in 14) and 16 had arterial occlusions. ${ }^{8}$ The leg veins were the most commonly reported site. ${ }^{9}$ Arterial thromboses are less common, and they usually affect the intracranial or extracranial cerebral arteries, in particular the territory supplied by the middle cerebral artery. ${ }^{10}$

In this paper we report the incidence of thrombotic episodes in a large series of children with SLE, and examine other clinical and laboratory features of SLE that may occur in association with these episodes.

\section{Patients and methods}

In 1986 we began a collaborative study of patients who fulfilled at least four of the diagnostic criteria for SLE as defined by the American College of Rheumatology, ${ }^{11}$ as well as the following conditions: patient admitted to hospitals in Paris or its immediate suburbs (departments 92, 93, and 94) in whom the disease was first diagnosed before the age of 16 and between January 1975 and December 1987. Drug induced disease was excluded. Given the nature of the French health system we can assume all children with SLE were admitted to hospital at least once and were therefore recorded in our study. Of the 120 patients who fulfilled these conditions 11 patients presented with thrombotic episodes and are described in detail. Because all patients with thrombotic episodes were between 10 and 16 years of age, their clinical and laboratory features were compared with those of 81 patients who did not develop thrombosis in the same age range. The significance of differences between groups was calculated by the $\chi^{2}$ test with Yates's correction.

In addition, we describe two interesting patients with thrombotic episodes who were thought to have SLE. They are excluded from our SLE group because we applied the American College of Rheumatology criteria strictly and they fulfilled only two or three of them.

Routine and immunological laboratory studies were done in different laboratories of the various hospitals, using standard techniques, and included antinuclear antibodies, anti-DNA antibodies, positive lupus erythematosus cell preparation, presence of antibodies to extractable nuclear antigens (ribonucleoprotein antigen or RNP, Sm antigen, Ro/Sjögren syndrome $A$ antigen or Ro/SSA, La/Sjögren syndrome $B$ antigen or $\mathrm{La} / \mathrm{SSB}$ ) and direct Coombs test. In addition, a false positive syphilis serology was ascertained when the Venereal Disease Research Laboratory reaction was positive and the Treponema pallidum haemagglutination or the fluorescent treponemal absorption test were negative.

On initial admission before treatment, most children had had complete coagulation profiles done including prothrombin time, kaolin
Philippe Reinert

Correspondence to: Accepted 21 January 1991 
cephalin clotting time (KCCT), platelet count, and individual factor assays. If either the prothrombin time or KCCT were prolonged, the presence of lupus anticoagulant was detected by measuring KCCT on a 1:1 mixture of citrated patient's plasma and pooled normal plasma. The presence of lupus anticoagulant was confirmed if a prolonged KCCT was not corrected by mixing it 1:1 with pooled normal plasma, which would be the case if the prolonged KCCT was the result of a deficit in coagulation factors.

\section{Results}

CLINICAL AND LABORATORY FEATURES OF PATIENTS WITH SLE AND THROMBOTIC EPISODES Eleven patients (eight girls and three boys) had at least one thrombotic episode (tables 1 and 2). All were over 10 years of age (mean age $11 \cdot 8$ ) and had a mean follow up of $8 \cdot 1$ years (range
3-13 years). Two girls were sisters (cases 6 and 7); they have been mentioned elsewhere. ${ }^{3}$

In seven children the thrombosis was one of the presenting symptoms. In five it was associated with typical symptoms of SLE, while in two it was isolated, and the diagnosis of SLE was only made one year (case 3 ) and three years (case 11) after the onset of disease. Six patients had only one thrombotic episode each, but five had more than one: recurrent venous thrombosis $(n=4)$, venous thrombosis and pulmonary embolism $(n=2)$, and arterial and venous thrombosis $(n=1)$. Of a total of 16 thrombotic episodes, 14 were in leg veins, and in four instances they were associated with pulmonary embolism. Two affected the territory of the middle cerebral arteries. Nine patients had venous thrombosis of leg veins: superficial veins $(n=5)$, both superficial and deep veins $(n=2)$, and deep veins $(n=2)$. Deep venous thrombosis was confirmed by phlebography and pulmon-

Table 1 Clinical characteristics of 11 patients with systemic lupus erythematosus who developed thromboses

\begin{tabular}{|c|c|c|c|c|c|c|}
\hline \multirow{2}{*}{$\begin{array}{l}\text { Case } \\
\text { No }\end{array}$} & \multirow[t]{2}{*}{ Sex } & \multirow{2}{*}{$\begin{array}{l}\text { Age at } \\
\text { onset } \\
\text { of disease } \\
\text { (years) }\end{array}$} & \multicolumn{2}{|l|}{ Thrombosis } & \multirow[t]{2}{*}{ Other clinical signs } & \multirow{2}{*}{$\begin{array}{l}\text { Follow up (years) } \\
\text { and outcome }\end{array}$} \\
\hline & & & Site & $\begin{array}{l}\text { Time after onset } \\
\text { of disease (years) }\end{array}$ & & \\
\hline 1 & $\mathbf{M}$ & $11 \cdot 0$ & $\begin{array}{l}\text { Superficial vein, left lower } \\
\text { leg (two episodes) }\end{array}$ & $1 \cdot 3$ and $7 \cdot 6$ & $\begin{array}{l}\text { Oral ulcers, vasculitis, pleural } \\
\text { effusion, thrombocytopenia, } \\
\text { leucopenia, proteinuria (focal } \\
\text { glomerular nephritis) }\end{array}$ & $\begin{array}{l}10 \cdot 0, \text { clinical } \\
\text { remission }\end{array}$ \\
\hline 2 & $\mathbf{M}$ & $14 \cdot 1$ & $\begin{array}{l}\text { Deep leg veins } \\
\text { Left femoropopliteal } \\
\text { Left iliofemoralpopliteal }\end{array}$ & $\begin{array}{l}4 \cdot 5 \\
7 \cdot 2\end{array}$ & $\begin{array}{l}\text { Malar rash, vasculitis, pancytopenia, } \\
\text { nephrotic syndrome (proliferative } \\
\text { glomerular nephritis) }\end{array}$ & $\begin{array}{l}6 \cdot 3 \text {, clinical } \\
\text { remission }\end{array}$ \\
\hline 3 & $\mathrm{~F}$ & $10 \cdot 1$ & $\begin{array}{l}\text { Superficial femoral vein } \\
\text { and pulmonary embolism }\end{array}$ & At onset & $\begin{array}{l}\text { Photosensitivity, polyarthritis, } \\
\text { leucopenia }\end{array}$ & $\begin{array}{l}4 \cdot 5 \text {, clinical } \\
\text { remission }\end{array}$ \\
\hline 4 & $\mathbf{F}$ & $13 \cdot 8$ & $\begin{array}{l}\text { Deep and superficial } \\
\text { iliofemoral veins }\end{array}$ & At onset & $\begin{array}{l}\text { Malar rash, photosensitivity, } \\
\text { vasculitis }\end{array}$ & $\begin{array}{l}3 \cdot 2 \text {, clinical } \\
\text { remission }\end{array}$ \\
\hline 5 & $\mathbf{F}$ & $11 \cdot 6$ & $\begin{array}{l}\text { Right iliofemoral vein and } \\
\text { pulmonary embolism }\end{array}$ & $2 \cdot 6$ & $\begin{array}{l}\text { Malar rash, vasculitis, } \\
\text { photosensitivity, polyarthritis }\end{array}$ & $\begin{array}{l}10 \cdot 5 \text {, clinical } \\
\text { remission }\end{array}$ \\
\hline 6 & $\mathbf{F}$ & $10 \cdot 7$ & Superficial right leg vein & At onset & $\begin{array}{l}\text { Oral ulcers, Raynaud's disease, } \\
\text { vasculitis, arthritis, pericarditis, } \\
\text { thrombocytopenia, leucopenia, } \\
\text { proteinuria }\end{array}$ & $3 \cdot 8$, death \\
\hline 7 & $\mathbf{F}$ & $11 \cdot 9$ & $\begin{array}{l}\text { Superficial lower leg vein } \\
\text { and pulmonary embolism } \\
\text { Deep iliofemoral vein }\end{array}$ & $\begin{array}{l}\text { At onset } \\
5 \cdot 8\end{array}$ & $\begin{array}{l}\text { Vasculitis, polyarthritis, proteinuria } \\
\text { proliferative glomerular nephritis, } \\
\text { fetal death at } 30 \text { weeks }\end{array}$ & $\begin{array}{l}11 \cdot 9 \text {, clinical } \\
\text { remission }\end{array}$ \\
\hline 8 & $\mathbf{F}$ & $10 \cdot 4$ & Superficial left leg vein & $1 \cdot 8$ & $\begin{array}{l}\text { Malar rash, nephrotic syndrome } \\
\text { (proliferative glomerular nephritis) }\end{array}$ & 10.9 , death \\
\hline 9 & $\mathbf{F}$ & $11 \cdot 4$ & $\begin{array}{l}\text { Superficial right leg vein } \\
\text { (two episodes) and } \\
\text { pulmonary embolism }\end{array}$ & At onset & $\begin{array}{l}\text { Haemolytic anaemia, } \\
\text { thrombocytopenia, proteinuria } \\
\text { (membranous glomerular nephritis) }\end{array}$ & $\begin{array}{l}13 \cdot 5 \text {, clinical } \\
\text { remission }\end{array}$ \\
\hline 10 & $\mathbf{F}$ & $11 \cdot 8$ & $\begin{array}{l}\text { Inferior vena cava and left } \\
\text { iliofemoral vein } \\
\text { Left middle cerebral } \\
\text { artery territory }\end{array}$ & $\begin{array}{l}\text { At onset } \\
8 \cdot 0\end{array}$ & $\begin{array}{l}\text { Malar rash, right side } \\
\text { paraesthesiae }\end{array}$ & $\begin{array}{l}12 \cdot 0, \text { clinical } \\
\text { remission }\end{array}$ \\
\hline 11 & $\mathbf{M}$ & $14 \cdot 3$ & $\begin{array}{l}\text { Right middle cerebral } \\
\text { artery territory }\end{array}$ & At onset & $\begin{array}{l}\text { Malar rash, thrombocytopenia, } \\
\text { leucopenia, proteinuria, left } \\
\text { hemiplegia, choreic like movements, } \\
\text { headaches, left hypoacousia, dysarthria }\end{array}$ & $3 \cdot 0$, death \\
\hline
\end{tabular}

Table 2 Laboratory features in 11 patients with systemic lupus erythematosus and thrombosis and in control subjects

\begin{tabular}{lllllll}
\hline $\begin{array}{l}\text { Case } \\
\text { No }\end{array}$ & $\begin{array}{l}\text { Anti-DNA } \\
\text { antibody }\end{array}$ & $\begin{array}{l}\text { Antinuclear } \\
\text { antibody }\end{array}$ & $\begin{array}{l}\text { Antibodies to } \\
\text { extractable nuclear } \\
\text { antigens present }\end{array}$ & $\begin{array}{l}\text { False positive } \\
\text { serology } \\
\text { for syphilis }\end{array}$ & $\begin{array}{l}\text { Coombs } \\
\text { test }\end{array}$ & $\begin{array}{l}\text { Lupus } \\
\text { anticoagulant }\end{array}$ \\
\hline 1 & Yes & Yes & Sm & ND & Yes & Yes \\
2 & Yes & Yes & No & No & Yo & Yo \\
3 & Yes & Yes & Ro/SSA & Yes & Yes & Yes \\
4 & Yes & Yes & No & Yes & Yes & Yes \\
5 & Yes & Yes & ND & Yes & Yes & Yes \\
6 & Yes & Yes & La/SSB & No & No & No \\
7 & Yes & Yes & ND & No & ND & Yes \\
8 & Yes & Yes & ND & Yes & Yes \\
9 & Yes & Yes & Sm & $8 / 47$ & $38 / 79$ & $13 / 100$ \\
10 & Yes & Nos & No & & &
\end{tabular}


ary embolism by isotopic lung scanning. One patient (case 10) had both arterial and venous lesions and one (case 11) had exclusively arterial thrombosis.

At onset case 10 presented with thrombosis of both the inferior vena cava and the left iliofemoral vein. Arterial thrombosis was presumed because cerebral computed tomography showed an ischeaemic lesion (area of hypodensity) in the left thalamic region eight years after onset and the patient had right sided paresthesiae. Arteriography was not done.

The other case of arterial thrombosis (case 11) presented at the onset of SLE with thrombosis of both superficial sylvian arteries that was confirmed by carotid arteriography. Computed tomography of the brain showed ischaemic lesions of the right tempororolandic area. He had episodes of occipital and temporal headaches associated with choreic type abnormal movements of his right side that preceded left hemiplegia, difficulties in pronunciation, diminution of visual acuity in the lower visual quadrants, and a left hearing deficit. He recovered the use of his left side, but continued to have headaches associated with visual impairment and abnormal choreic type movements of the right side. Apart from the initial overt infarction within the territory of the middle cerebral artery, transient ischaemic attacks might explain the severe headaches and the transitory visual impairments with which he presented. He died of acute pancreatitis presumably related to SLE, though an infective cause cannot be excluded. He was the only patient who lacked 'typical' anti-DNA and antinuclear antibodies.

Three patients (cases 1, 2, and 6) had haemorrhagic syndromes that presented with purpura and ecchymosis. All had severe thrombocytopenia (platelet count less than $\left.100 \times 10^{9} / 1\right)$.

Lupus anticoagulant was found in eight of the 11 patients (table 2). In most of them it was repeatedly measured and found either to persist or to become positive after several years of follow up. There was only one exception (case 6) in whom it became negative three years after onset of disease.

All the patients with SLE received comparable doses of steroids when the disease was diagnosed; patients with thromboses also received anticoagulants. At the time of writing eight of the patients were in remission (table 1). Three patients died, though none from complications of their thrombotic episodes: one died of pancreatitis (case 11), one of myocarditis (case 6), and one of rupture of the arterial suture immediately after renal transplantation (case 8). This patient was the only one with thrombotic episodes who developed end stage renal failure.

When the incidence of vasculitis, lupus anticoagulant, positive Coombs test, and the presence of American College of Rheumatology diagnostic criteria for SLE in this group of patients was compared with that among patients without thrombotic complications, the only significant difference was in the presence of a lupus anticoagulant: eight of $11(73 \%)$ of patients with SLE and thrombotic (arterial or venous) episodes had lupus anticoagulant, compared with only 13 of 100 patients who had no thrombotic episodes $(p<0.001)$. Nine patients in our series did not have coagulation profiles done.

THROMBOTIC EPISODES IN TWO PATIENTS WITH LESS THAN FOUR CRITERIA FOR SLE

Two patients with less than four American College of Rheumatology criteria for SLE (one boy and one girl) presented with thrombotic episodes. The boy had non-painful swelling of his left lower limb and phlebography showed chronic thrombotic occlusion of the popliteal, femoral, and saphenous veins. In addition, he had anti-DNA antibodies, false positive serology for syphilis, thrombocytopenia, and positive lupus anticoagulant. Treated with hydroxychloroquine, he is doing well after 10 years follow up.

The girl presented with thrombocytopenia, positive lupus anticoagulant, false positive serology for syphilis, low titres of anti-DNA antibodies, anaemia with a positive direct Coombs test, and primary acute adrenal insufficiency in addition to deep venous thrombosis of lower limbs. Antibodies against adrenal tissue were not determined and an adrenal venogram was not done. She was treated with cortisone and fludrocortisone and at the time of writing was doing well after nine years of follow up.

\section{Discussion}

Eleven children (9\%) in our series of 120 patients with SLE had single or recurrent thrombotic episodes. Most of the episodes were venous. Thrombotic episodes in the absence of certain risk factors are uncommon in children, and the diagnosis of SLE must be considered. Inherited factors predisposing to thrombosis, however, must also be evaluated. In our retrospective study protein $S$ and protein $C$ concentrations in plasma were not determined and antithrombin III deficiency was not investigated.

Children with SLE and thrombotic episodes have only been described in case reports to our knowledge. Olive et al described a 9 year old boy who had extensive thrombosis of the inferior vena cava and femoral veins associated with thrombocytopenia and haemolytic anaemia as the presenting sign of SLE. ${ }^{1}$ St Clair et al described a 14 year old boy with painless swelling of his right thigh; SLE was subsequently confirmed. ${ }^{2}$ Bernstein et al discussed two girls aged 10 and 14 who presented with recurrent venous thrombosis and positive lupus anticoagulant. ${ }^{4}$ The first patient had confirmed SLE with deep venous thrombosis of the lower extremities, and the older one had positive antiDNA antibodies and false positive serology for syphilis associated with Budd-Chiari syndrome and superficial thrombosis of the leg veins. A boy aged 12 , one of the children described by Pelkonen et al, presented with thrombosis of the femoral vein, pulmonary embolism, thrombocytopenia, anti-DNA antibody and lupus anticoagulant. $^{5}$ He developed obvious SLE 
three years later. All these patients had positive lupus anticoagulant and were treated with anticoagulants in addition to corticosteroids. A 5 year old girl reported by Appan et al had SLE with haemolytic anaemia as the presenting symptom followed a year later (when corticosteroid treatment was interrupted) by multiple arterial thromboses of the brain and retina and peripheral venous thrombosis of both hands and feet. She had a positive lupus anticoagulant. ${ }^{6}$ Recently renal artery thrombosis and hypertension with positive lupus anticoagulant were reported in a 13 year old girl with SLE. ${ }^{7}$ She also had neurological symptoms and a computed tomogram suggestive of cerebral thrombosis. She was treated with prednisone, antihypertensive drugs, and anticoagulants and her condition was satisfactory. No deaths were reported by these authors. In our series three patients died, none from complications of their thrombotic episodes.

We also described two other patients with thrombotic episodes who did not fulfill the American College of Rheumatology criteria for SLE. One of them presented with adrenal insufficiency. Case reports of thrombotic complications in young patients with lupus anticoagulant without clear cut SLE are rare. Kelley and Berger reported a 16 year old girl with a right middle cerebral occlusion and deep venous thrombosis of the lower limbs associated with lupus anticoagulant, false positive syphilis serology, and antinuclear antibodies, but who had less than four of the criteria for SLE. ${ }^{12}$ Two boys aged 12 and 13 years old were described by Ravelli et al; they had deep venous thrombosis associated with anticardiolipin antibody and lupus anticoagulant. ${ }^{13}$ One had low titres of antinuclear antibody. Pelkonen et al reported on a 10 year old girl with thrombosis of the vena cava and both iliac veins who had initially presented with adrenal insufficiency. ${ }^{5}$ Apart from these only adult case reports have associated acute adrenal insufficiency with recurrent deep venous thrombosis and antiphospholipid antibodies. ${ }^{14} 15$ As to the aetiology and pathogenesis, the reported absence of antibodies to adrenal tissue seems to negate the autoimmune hypothesis, and the possibility of bilateral adrenal vein thrombosis should be considered. In our patient with adrenal insufficiency, antibodies against adrenal tissue were not measured, and as the possibility of venous thrombosis was not suspected at the time, an adrenal venogram was not done.

In our series a significant number of the children with SLE and thrombotic episodes had positive lupus anticoagulant compared with those who had no history of thrombosis. Adult series have extensively documented this association since Bowie et al first described it in 1963. ${ }^{16}$ The lupus anticoagulants are a spontaneously acquired population of antibodies (IgM, IgG) initially described in SLE patients ${ }^{17}$ that interfere with in vitro phospholipid dependent coagulation reactions. ${ }^{18}$ Bleeding is uncommon in the absence of associated severe thrombocytopenia, qualitative platelet defects, hypoprothrombinaemia, or coagulation factor deficiencies. ${ }^{19}$ The lack of standardisation and the differing sensitivities of various assays to detect lupus anticoagulant, as well as differences in patient populations, make comparisons between different studies difficult and probably account for incidences that vary from $6-18 \%^{19}$ to $40-50 \% .^{20}$ In our series, $21 / 111(19 \%)$ of our patients with SLE had lupus anticoagulant. At present, diagnosis of lupus anticoagulant should be strengthened by confirmatory studies using the tissue thromboplastin inhibition test, the dilute Russell viper venom time, or the platelet neutralisation procedure. ${ }^{21}$ The anticardiolipin antibody was not measured in our retrospective series. It is a sensitive test for the detection of antiphospholipid antibodies, and its determination is becoming increasingly important.

Several hypotheses were reviewed in a recent paper to try to explain the relationship between antiphospholipid antibodies and thrombosis, but at present it cannot be said if lupus anticoagulant is the cause, the result, or an epiphenomenon of thrombosis. ${ }^{21}$ Given the phospholipid specificity of lupus anticoagulant, alterations in either endothelial or platelet membrane functions would seem the most likely explanations for lupus anticoagulant induced thrombotic complications. It has been hypothesised that lupus anticoagulant may increase coagulant properties by decreasing anticoagulant systems that depend on the endothelium. ${ }^{21}$ The affinity of the lupus anticoagulant for phospholipids might explain its reported association with thrombocytopenia, ${ }^{9}$ and false positive syphilis reactions. ${ }^{19}$ Lupus anticoagulant fixation on phospholipid membranes might lead to peripheral destruction. Cross reactions with the cardiolipin antigen used in Venereal Disease Research Laboratory reactions might explain the high percentages of false positive serology for syphilis in patients with lupus anticoagulant.

In adult series, a syndrome consisting of a tendency to recurrent thrombosis together with recurrent mid-pregnancy fetal loss, ${ }^{22}$ thrombocytopenia, haemolytic anaemia, ${ }^{23}$ livedo reticularis, ${ }^{24}$ valvular heart disease, ${ }^{10} 2526$ and chorea associated with antibodies against phospholipids, has been proposed. ${ }^{27} 28$ Severe migrainous headaches may antedate other cerebral vascular symptoms. ${ }^{29}$ Case 11 with arterial thrombotic episodes had had severe headaches five years before diagnosis of disease.

Alarcon Segovia et al argue that patients with and without SLE but who have at least two features significantly associated with the presence of anticardiolipin antibodies (venous thrombosis, thrombocytopenia, haemolytic anaemia, leg ulcers, or recurrent fetal loss) in addition to antiphospholipid antibodies, should be included in a antiphospholipid syndrome. ${ }^{8}$ The identification of a more homogeneous subset of patients might provide new insights into the pathophysiology and the treatment of the antiphospholipid syndrome and of SLE as well.

Our reported incidence of thrombosis in childhood onset SLE is rarely reflected in published reports, but merits attention. Even if currently required standardised procedures for determining lupus anticoagulant were not entirely satisfied, given the retrospective nature of our study, our data are strongly suggestive of 
a relationship between lupus anticoagulant and thrombosis in SLE in childhood. Though there is at present no test that can predict which patients will actually develop symptoms, lupus anticoagulant (or anticardiolipin antibodies, or both) should be determined to screen patients at risk for thrombotic complications (including recurrent abortions in older female patients). Data accumulated so far do not justify therapeutic interventions on the basis of the presence of a lupus anticoagulant alone, and in our series long term anticoagulant treatment was avoided in children with thrombotic episodes because of the haemorrhagic risk during play and sport. An increasing number of patients with lupus anticoagulant with or without clear cut SLE are, however, receiving long term treatment with low doses of aspirin to reduce the risk of recurrent thrombosis. ${ }^{25} 29$

The study was supported by MGEN contract number 3926 , Paris, France.

1 Olive D, André E, Brocard O, Labrude P, Alexandre P. Lupus érythémateux disséminé revélé par des thrombophlébites des membres infériurs. Arck Fr Pediatr 1979;36: 807-11.

2 St Clair W, Jones B, Rogers JS, Crouch M, Hrabovsky E. Deep venous thrombosis and a circulating anticoagulant in systemic.

3 Perraudin ML, Rousseau A, Desbois LC, Herrault A, Lévêque $B$. Thromboses veineuses, anticoagulant circulan et lupus erythémateux disséminé. A propos de 2 cas chez 2 sœurs HLA idéntiques. Ann Pediatr (Paris) 1981;28:251-9.

4 Bernstein ML, Salusinsky-Sternbach $M$, Bellefleur $M$, Esseltine DW. Thrombotic and hemorrhagic complication in children with the lupus anticoagulant. Am $\mathcal{F}$ Dis Child 1984;138:1132-5.

5 Pelkonen $P$, Simell O, Rasi V, Vaarala O. Venous thrombosis associated with lupus anticoagulant and anticardiolipin antibodies. Acta Paediatr Scand 1988;77:767-72. 6 Appan S, Boey ML, Lim KW. Multiple thromboses in 739-41.

7 Ostuni PA, Lazzarin P, Pengo V, Ruffatti A, Schiavon F, Gambari $P$. Renal artery thrombosis and hypertension in a Gambari P. Renal artery thrombosis and hypertension in a
13 year old girl with antiphospholipid syndrome. Ann

8 Alarcon Segovia D, Delezé M, Oria CV, et al. Antiphospholipid antibodies and the antiphospholipid syndrome in pholipid antibodies and the antiphospholipid syndrome in
systemic lupus erythematosus. A prospective analysis of systemic lupus erythematosus. A prospective analysis
500 consecutive patients. Medicine 1989;68:353-65.

9 Lechner K, Pabinger-Fasching I. Lupus anticoagulants and thrombosis. A study of 25 cases and a review of the literature. Haemostasis 1985;15:254-62.

10 Asherson RA, Lubbe WF. Cerebral and valve lesions in SLE association with antiphospholipid antibodies. $\mathcal{F}$ Rheumato 1988;15:539-43.

11 Tan EM, Cohen AS, Fries JF, et al. The 1982 revised criteria for the classification of systemic lupus erythematosus. Arthritis Rheum 1982;25:1271-7.
12 Kelley RE, Berger JR. Ischemic stroke in a girl with lupus anticoagulant. Pediatric Neurology 1987;3:58-61.

13 Ravelli A, Caporali R, Bianchi E, et al. Anticardiolipin syndrome in childhood: a report of two cases. Clin Exp Rheumatol 1990;8:95-8.

14 Asherson RA, Hughes GRV. Recurrent deep vein thrombosis and Addison's disease in 'primary' antiphospholipid synand Addison's disease in 'primary' an

15 Carette S, Jobin F. Acute adrenal insufficiency as a manifestation of the anticardiolipin syndrome? Ann Rheum Dis festation of the
$1989 ; 48: 430-1$.

16 Bowie EJW, Thompson JH, Pascuzzi CA, Owen CA. Thrombosis in systemic lupus erythematosus despite circulating anticoagulants. $\mathcal{F}$ Lab Clin Med 1963;62: 416-30.

17 Conley CL, Hartmann RC. A hemorrhagic disorder caused by circulating anticoagulant in patients with disseminated lupus erythematosus. F Clin Invest 1952;31:621-2.

18 Feinstein DI, Rappaport SI. Acquired inhibitors of blood coagulation. Prog Hemost Thromb 1972;1:75-95.

19 Shapiro SS, Thiagarajan P. Lupus anticoagulants. Prog Hemost Thromb 1982;6:263-85.

20 Derksen RHWM, Hasselaar P, Blokzijl L, Gmelig Meyling FHJ, de Groot PG. Coagulation screen is more specific than the anticardiolipin antibody ELISA in defining a thrombotic subset of lupus patients. Ann Rheum Dis 1988;47: tic subset

21 Triplett DA, Brandt JT. Lupus anticoagulants: misnomer, paradox, riddle, epiphenomenon. Hematologic Pathology 1988;2:121-43.

22 Lubbe WF, Liggins GC. Lupus anticoagulant and pregnancy. Am f Obstet Gynecol 1985;153:322-7.

23 Delezé M, Oria CV, Alarcon-Segovia D. Occurrence of both hemolytic anemia and thrombocytopenic purpura (Evan's syndrome) in systemic lupus erythematosus. Relationship to antiphospholipid antibodies. $\mathcal{F}$ Rheumatol 1988;15: 611-5.

24 McHugh NJ, Maymo J, Skinner RP, James I, Maddison PJ. Anticardiolipin antibodies, livedo reticularis and majo cerebrovascular and renal disease in systemic lupus erythematosus. Ann Rheum Dis 1988;47:110-5.

25 Chartash EK, Lans DM, Paget SA, Qamar T, Lockshin MD. Aortic insufficiency and mitral regurgitation in patients with systemic lupus erythematosus and the antiphospholipid syndrome. Am $\mathcal{F}$ Med 1989;86:407-12.

26 Ford PM, Ford SE, Lillicrap DP. Association of lupus anticoagulant with severe valvular heart disease in systemic coagulant with severe valvular heart disease in system
lupus erythematosus. 7 Rheumatol $1988 ; 15: 597-600$.

27 Harris EN, Hughes GRV, Gharavi AE. Antiphospholipid antibodies: an elderly statesman dons new garments. antibodies: an elderly states

28 Hughes GRV, Harris KN, Gharavi AE. The anticardiolipin syndrome. F Rhematol 1986;13:486-9.

29 Asherson RA, Khamashta MA, Gil A, et al. Cerebrovascular disease and antiphospholipid antibodies in systemic lupus erythematosus, lupus-like disease, and the primary antiphospholipid syndrome. Am F Med 1989;86:391-9.

\section{Addendum}

Since the submission of this article a girl, aged 10.5 years at onset of SLE, presented with thrombosis of a superficial lower leg vein 13 years later. She had initially presented with malar rash, polyarthritis, vasculitis, positive lupus erythematosus cell preparation, direct Coombs test, antinuclear and anti-DNA antibodies. No lupus anticoagulant was initially done. 